\title{
Microbacterium sediminis sp. nov., a psychrotolerant, thermotolerant, halotolerant and alkalitolerant actinomycete isolated from deep-sea sediment
}

Correspondence

Xixiang Tang

tangxixiang@hotmail.com

\author{
Libo Yu, ${ }^{1} \dagger$ Qiliang Lai, ${ }^{1}$ † Zhiwei Yi, ${ }^{1}$ Limin Zhang, ${ }^{2}$ Ying Huang, ${ }^{2}$ Li Gu ${ }^{1}$ \\ and Xixiang Tang ${ }^{1}$
}

${ }^{1}$ Key Laboratory of Marine Biogenetic Resources, Third Institute of Oceanography, State Oceanic Administration, Xiamen 361005, PR China

${ }^{2}$ State Key Laboratory of Microbial Resources, Institute of Microbiology, Chinese Academy of
Sciences, Beijing 100101, PR China

An aerobic, rod-shaped, Gram-positive, oxidase- and catalase-positive bacterial isolate, strain YLB- $01^{\top}$, was characterized using phenotypic and molecular taxonomic methods. 16S rRNA gene sequence analysis revealed that the isolate belonged to the genus Microbacterium and represented an evolutionary lineage that was distinct from recognized species of the genus Microbacterium. The isolate showed $<97 \% 16 \mathrm{~S}$ rRNA gene sequence similarity with respect to the type strains of all of the members of the genus Microbacterium with validly published names. Cell-wall hydrolysate from the isolate contained the amino acids ornithine, alanine, glycine homoserine and glutamic acid, and the cell-wall sugars consisted of ribose, glucose and galactose. The main respiratory quinones were MK-8, 9, 10 and 11 . The major cellular fatty acids were anteiso- $\mathrm{C}_{15: 0}(38.5 \%)$, anteiso- $\mathrm{C}_{17: 0}(23.1 \%)$ and $\mathrm{C}_{16: 0}(18.9 \%)$. The polar lipids contained diphosphatidylglycerol, phosphatidylglycerol, an unidentified phospholipid and two unidentified glycolipids. The DNA G $+\mathrm{C}$ content of strain $\mathrm{YLB}-01^{\top}$ was $71 \mathrm{~mol} \%$. On the basis of the morphological, physiological and chemotaxonomic data and the results of comparative $16 \mathrm{~S}$ rRNA gene sequence analysis, this isolate represents a novel species of the genus Microbacterium, for which the name Microbacterium sediminis sp. nov. is proposed. The type

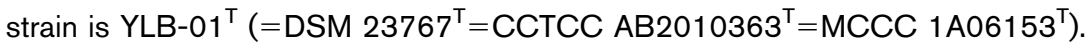

Recent study of the microbial diversity of deep-sea sediments has shown that this environment might contain $>1300$ different actinobacterial operational taxonomic units, a great proportion of which are predicted to represent novel species and genera (Stach \& Bull, 2005). This study focused on isolating new actinomycetes from deep-sea sediments, and one novel strain of the genus Microbacterium was found. The genus Microbacterium was described by Orla-Jensen (1919) and belongs to the family Microbacteriaceae. Strains of the genus Microbacterium are widespread and have been isolated from various environmental sources (Collins \& Bradbury, 1992), including soil, water, plants, clinical samples and deep-sea sediments. At the time of writing, the genus Microbacterium comprises

†These authors contributed equally to this paper.

The GenBank/EMBL/DDBJ accession number for the 16S rRNA gene sequence of strain $\mathrm{YLB}^{-01^{\top}}$ is $\mathrm{HQ} 219727$.

Six supplementary figures are available with the online version of this paper.
73 species with validly published names (http://www. bacterio.cict.fr/).

Strain YLB- $01^{\mathrm{T}}$ was isolated from a sediment sample collected at $2327 \mathrm{~m}$ water depth, at a site $\left(49.8405^{\circ} \mathrm{E}\right.$ $37.8111^{\circ} \mathrm{S}$ ) in the south-west Indian Ocean in November 2008 during the cruise of ' $\mathrm{Da}$-Yang Yi-Hao'. Two grams of soil was suspended in $18 \mathrm{ml}$ sterile seawater and mixed. Soil particles were allowed to sediment, the liquid phase was diluted $10^{5}$-fold and $100 \mu \mathrm{l}$ samples were spread onto the surface of each cultivation plate. FJ agar plates $(1 \%$ glucose, $1 \%$ yeast extract, $1.5 \%$ agar, $50 \%$ seawater) with rifampicin $\left(5 \mathrm{mg} \mathrm{l}^{-1}\right)$ and potassium dichromate $\left(50 \mathrm{mg} \mathrm{l}^{-1}\right)$ were used, and were cultured at $28{ }^{\circ} \mathrm{C}$. Biomass for biochemical and chemotaxonomic study was prepared by culturing on trypticase soy agar (TSA) medium at $28{ }^{\circ} \mathrm{C}$ followed by cell harvesting (Bakir et al., 2008).

DNA extraction was performed as described earlier (Xu et al., 2007), and the crude DNA obtained was purified by an EZNA. Cycle-Pure kit (Omega Bio-Tek). Universal 
primers, PCR conditions and sequencing were as described by Chun \& Goodfellow (1995). The almost-complete $16 \mathrm{~S}$ rRNA gene sequence (1487 bp) of strain $\mathrm{YLB}-01^{\mathrm{T}}$ was obtained and analysed using BLAST searches against the GenBank and EzTaxon databases (Altschul et al., 1997; Chun et al., 2007). The $16 \mathrm{~S}$ rRNA gene sequences of closely related taxa obtained from the GenBank database were aligned using CLUSTAL x (Thompson et al., 1997). Phylogenetic trees were constructed by using the neighbour-joining, minimumevolution and maximum-parsimony methods with MEGA3.1 software (Kumar et al., 2004; Saitou \& Nei, 1987). The topologies of the trees were evaluated by performing a bootstrap analysis using 1000 replications (Felsenstein, 1985). Clustering results using the minimum-evolution and maximum-parsimony approaches (Figs S1 and S2 available in IJSEM Online) were similar to that obtained using the neighbour-joining method.

Phylogenetic analysis showed that strain YLB- $01^{\mathrm{T}}$ formed a clade within the genus Microbacterium (Fig. 1). Its closest relatives were Microbacterium hatanonis DSM $19179^{\mathrm{T}}(96.9 \%$ 16S rRNA gene sequence similarity), Microbacterium testaceum DSM 20166 ${ }^{\mathrm{T}}$ (96.9\%), Microbacterium kitamiense Kitami C2 ${ }^{\mathrm{T}}(96.9 \%)$, Microbacterium phyllosphaerae DSM $13468^{\mathrm{T}}(96.8 \%)$ and Microbacterium hydrocarbonoxydans DSM $16089^{\mathrm{T}}(96.8 \%)$; levels of sequence similarity to other species tested were below $96.8 \%$. 16S rRNA gene sequence divergences between strain YLB- $01^{\mathrm{T}}$ and recognized species of the genus Microbacterium were $\geqslant 3.1 \%$, and thus the data support the suggestion that strain YLB- $01^{\mathrm{T}}$ represents a novel

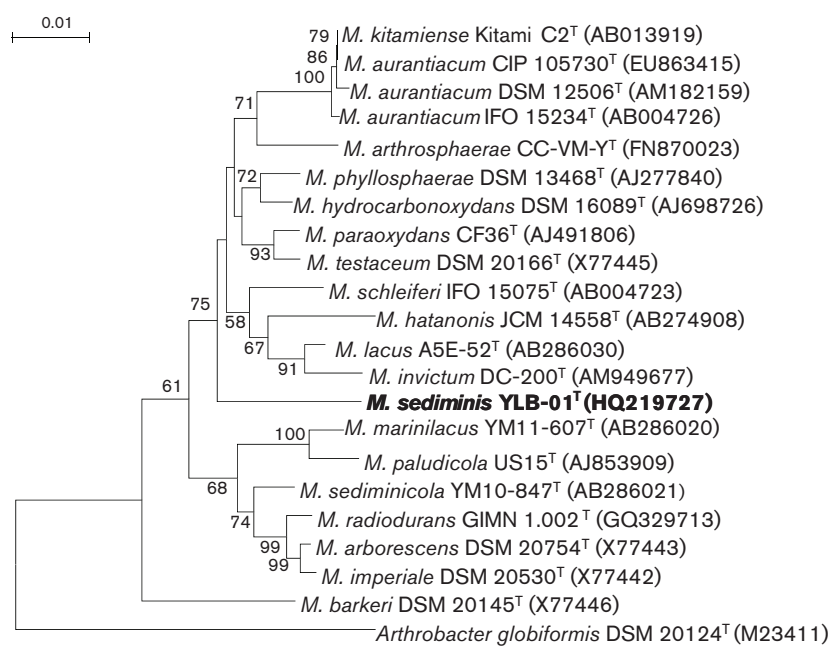

Fig. 1. Phylogenetic tree derived from $16 \mathrm{~S}$ rRNA gene sequences created using the neighbour-joining method, showing the phylogenetic position of strain $\mathrm{YLB}-01^{\top}$. Numbers at branch points are bootstrap percentages (based on 1000 resamplings). Arthrobacter globiformis DSM $20124^{\top}$ served as the outgroup. Bar, 0.01 accumulated changes per nucleotide. A more complete tree is shown in Fig. S6. species according to the standards proposed by Schumann \& Evtushenko (2006).

Morphological observation under a scanning electron microscope (JEM-1230; JEOL) was performed on cultures grown on TSA at $28{ }^{\circ} \mathrm{C}$ for $24 \mathrm{~h}$. The Gram-reaction, and catalase and oxidase activities were studied as previously described (Lai et al., 2009). The ability to grow at various $\mathrm{NaCl}$ concentrations $(0,1,2,3,4,5,6,7,8,9$ and $10 \%$, $\mathrm{w} / \mathrm{v}$ ) and $\mathrm{pH}$ values (from 4.0 to 12.0 ) were determined at $28{ }^{\circ} \mathrm{C}$ using TSA medium. Growth at different temperatures $\left(4,10,20,25,28,30,37,45,50,55\right.$ and $\left.60{ }^{\circ} \mathrm{C}\right)$ was tested on TSA. Isolate YLB- $01^{\mathrm{T}}$ and reference strains $M$. hatanonis DSM $19179^{\mathrm{T}}$, M. testaceum DSM 20166 ${ }^{\mathrm{T}}$, M. phyllosphaerae DSM $13468^{\mathrm{T}}$ and M. hydrocarbonoxydans DSM $16089^{\mathrm{T}}$ were characterized biochemically by using the API 20NE, API ZYM and API 50CH systems according to the manufacturer's instructions (bioMérieux).

Cells of strain YLB- $01^{\mathrm{T}}$ were aerobic, rod-shaped, Grampositive, oxidase-positive, catalase-positive and motile, and with cell size in the range $0.4-0.7 \times 0.8-1.7 \mu \mathrm{m}$ (Fig. S3). Colonies were circular, convex with entire margins, moist and white in colour. The isolate grew at $4-50{ }^{\circ} \mathrm{C}$, at a maximum $\mathrm{NaCl}$ concentration of $8 \%$ and at $\mathrm{pH} 5.0-10.0$. Optimum growth was observed at $28{ }^{\circ} \mathrm{C}$ without the addition of $\mathrm{NaCl}$.

The G+C content of the chromosomal DNA was determined according to the methods described by Mesbah et al. (1989) using reversed-phase HPLC. The DNA G + C content of the new isolate YLB- $01^{\mathrm{T}}$ was $71 \mathrm{~mol} \%$ and was in the range for species of the genus Microbacterium (66.5-71.6 mol\%; Takeuchi \& Hatano, 1998a).

Fatty acids of whole cells of strain YLB- $01^{\mathrm{T}}$ grown on TSA at $28{ }^{\circ} \mathrm{C}$ for $48 \mathrm{~h}$ were extracted, saponified and esterified; this was followed by GC analysis of the fatty acid methyl esters according to the instructions of the MIDI system (Microbial ID, Inc.; Method TSBA6; version 6.0B; Agilent Technologies 6850) (Sasser, 1990). The fatty acid profiles of strain YLB- $01^{\mathrm{T}}$ were determined in parallel with those of $M$. hatanonis DSM $19179^{\mathrm{T}}$, M. testaceum DSM 20166 ${ }^{\mathrm{T}}$, M. phyllosphaerae DSM $13468^{\mathrm{T}}$ and M. hydrocarbonoxydans DSM $16089^{\mathrm{T}}$ in this study. The results are shown in Table 1. The major fatty acids were anteiso- $\mathrm{C}_{15: 0}$, anteiso- $\mathrm{C}_{17: 0}$ and $\mathrm{C}_{16: 0}$, which accounted for $>75 \%$ of the total fatty acids. Strain YLB- $01^{\mathrm{T}}(18.9 \%)$ differed from the other strains $(2.0-8.3 \%)$ in the proportion of $\mathrm{C}_{16: 0}$, which could be used as a distinguishing characteristic. Polar lipids of strain YLB- $01^{\mathrm{T}}$ were analysed in parallel with those of $M$. testaceum DSM $20166^{\mathrm{T}}$. Polar lipids were extracted and identified by two-dimensional TLC (Merck silica gel $60 \mathrm{~F} 254,10 \times 10 \mathrm{~cm}$, aluminium-backed thin-layer plates) according to the method of Minnikin et al. (1984). The TLC plates were sprayed with specific reagents for total lipids (molybdatophosphoric acid), phospholipids (Dittmer and Lester reagents) and glycolipids ( $\alpha$-naphthol). The polar lipids of strain YIB$01^{\mathrm{T}}$ contained diphosphatidylglycerol, phosphatidylglycerol, 
Table 1. Whole-cell fatty acid compositions (\%) of strain YLB- $01^{\top}$ and the type strains of related Microbacterium species

Strains: 1, YLB-01 ${ }^{\mathrm{T}}$; 2, M. hatanonis DSM 19179 ${ }^{\mathrm{T}}$; 3, M. testaceum DSM 20166 ${ }^{\mathrm{T}}$; 4, M. kitamiense Kitami C2 ${ }^{\mathrm{T}}$ (data from Matsuyama et al., 1999); 5, M. phyllosphaerae DSM $13468^{\mathrm{T}}$; 6, M. hydrocarbonoxydans DSM $16089^{\mathrm{T}} ; 7$, M. aurantiacum IFO $15234^{\mathrm{T}}$ (Takeuchi \& Hatano, 1998a); 8, M. schleiferi IFO $15075^{\mathrm{T}}$ (Bakir et al., 2008); 9, M. barkeri DSM 20145 ${ }^{\mathrm{T}}$ (Young et al., 2010); 10, M. paraoxydans CF36 ${ }^{\mathrm{T}}$ (Madhaiyan et al., 2010); 11, M. profundi $\mathrm{Shh} 49^{\mathrm{T}}$ (Wu et al., 2008). Data are from this study except where noted. -, Negative; ND, no data available; tr, trace amount $(<1.0 \%)$.

\begin{tabular}{|c|c|c|c|c|c|c|c|c|c|c|c|}
\hline Fatty acid & 1 & 2 & 3 & 4 & 5 & 6 & 7 & 8 & 9 & 10 & 11 \\
\hline \multicolumn{12}{|c|}{ Saturated fatty acids } \\
\hline $\mathrm{C}_{14: 0}$ & 2.8 & 1.1 & $\operatorname{tr}$ & ND & 1.3 & $\operatorname{tr}$ & ND & - & $\operatorname{tr}$ & $\operatorname{tr}$ & - \\
\hline $\mathrm{C}_{18: 0}$ & 6.0 & $\operatorname{tr}$ & $\operatorname{tr}$ & ND & 3.3 & 1.2 & 5.0 & $\operatorname{tr}$ & ND & ND & $\mathrm{ND}$ \\
\hline $\mathrm{C}_{19: 0}$ & - & - & $\operatorname{tr}$ & ND & - & 1.7 & $\mathrm{ND}$ & - & ND & ND & $\mathrm{ND}$ \\
\hline \multicolumn{12}{|c|}{ Unsaturated fatty acids } \\
\hline $\mathrm{C}_{18: 1} \omega 9 c$ & - & - & - & ND & $\operatorname{tr}$ & - & ND & - & ND & $\mathrm{ND}$ & $\mathrm{ND}$ \\
\hline \multicolumn{12}{|c|}{ Branched fatty acids } \\
\hline iso- $\mathrm{C}_{14: 0}$ & 1.7 & $\operatorname{tr}$ & $\operatorname{tr}$ & ND & $\operatorname{tr}$ & $\operatorname{tr}$ & - & $\operatorname{tr}$ & - & - & 2.5 \\
\hline iso- $\mathrm{C}_{15: 0}$ & 1.0 & $\operatorname{tr}$ & 5.4 & ND & 4.3 & 4.7 & 4.0 & $\operatorname{tr}$ & 1.8 & 12.5 & 15.0 \\
\hline anteiso- $\mathrm{C}_{15: 0}$ & 38.5 & 48.1 & 43.6 & $40-47$ & 40.9 & 44.4 & 36.1 & 55.0 & 42.1 & 39.5 & 60.9 \\
\hline iso- $\mathrm{C}_{16: 0}$ & 14.1 & 12.5 & 20.5 & $10-13$ & 21.7 & 15.2 & 20.6 & 11.3 & 28.4 & 14.5 & 11.7 \\
\hline
\end{tabular}

an unidentified phospholipid and two unidentified glycolipids (Fig. S4).

Analyses of quinones, peptidoglycan structure and cell-wall sugars were performed by the identification service of the Deutsche Sammlung von Mikroorganismen und Zellkulturen (DSMZ, Braunschweig, Germany). Respiratory lipoquinones were extracted and analysed by the method described by Tindall (1990a, b). Analysis of the peptidoglycan was performed using TLC, two-dimensional TLC, GC and GC/ MS (Schleifer, 1985; MacKenzie, 1987; Groth et al., 1996). For analysis of the whole-cell sugars of strain $\mathrm{YLB}-01^{\mathrm{T}}$, cells were hydrolysed in $0.5 \mathrm{M} \mathrm{H}_{2} \mathrm{SO}_{4}\left(2 \mathrm{~h}\right.$ at $\left.100{ }^{\circ} \mathrm{C}\right) . \mathrm{H}_{2} \mathrm{SO}_{4}$ was removed by $20 \% \mathrm{~N}, \mathrm{~N}$-dioctylmethylamine in chloroform according to Whiton et al. (1985) and sugars in the hydrolysate were analysed by TLC on cellulose plates according to Staneck \& Roberts (1974).

The menaquinones were MK-10 (32\%), MK-11 (25\%), MK-8 (20\%), MK-9 (17\%) and MK-12 (3\%) and some unidentified minor components (Fig. S5). The total hydrolysate (4 M HCl, $100{ }^{\circ} \mathrm{C}, 16 \mathrm{~h}$; Schleifer, 1985) of the peptidoglycans of strain YLB- $01^{\mathrm{T}}$ contained the amino acids ornithine, alanine, glycine homoserine and glutamic acid. The peptidoglycan was of type B2 $\beta$. The whole-cell sugars of strain YLB- $01^{\mathrm{T}}$ contained ribose, glucose and galactose; the type strains of related species analysed here lacked ribose (Table 2). The cell-wall diamino acid of strain YLB- $01^{\mathrm{T}}$ was ornithine. These traits are in accordance with the properties of its closest relatives (Behrendt et al., 2001; Bakir et al., 2008; Schippers et al., 2005; Schumann et al., 1999; Takeuchi \& Hatano, 1998a).

Strain $\mathrm{YLB}-01^{\mathrm{T}}$ differed clearly from phylogenetically related species (Table 2): for instance, in contrast to $M$. phyllosphaerae, it utilized D-fructose, $\alpha$-D-glucose, D-mannose and D-sorbitol as a sole carbon source, and produced $\mathrm{N}$ acetyl- $\beta$-glucosaminidase. The major quinones and cell-wall sugars of strain YLB- $01^{\mathrm{T}}$ were different from those of $M$. phyllosphaerae. The novel strain was able to grow under more extreme conditions than its nearest neighbours: at $4{ }^{\circ} \mathrm{C}$, at $50{ }^{\circ} \mathrm{C}$, at a maximum $\mathrm{NaCl}$ concentration of $8 \%$ and at $\mathrm{pH}$ 10.0. Consequently, strain YLB- $01^{\mathrm{T}}$ is psychrotolerant, thermotolerant, halotolerant and alkalitolerant. Colonies of strain YLB- $01^{\mathrm{T}}$ were white, whereas those of M. phyllosphaerae were yellow. On the basis of morphological, physiological and chemotaxonomic characteristics, together with data from 16S rRNA gene sequence comparisons, strain YLB- $01^{\mathrm{T}}$ should be placed in a novel species within the genus Microbacterium, for which the name Microbacterium sediminis sp. nov. is proposed.

\section{Description of Microbacterium sediminis sp. nov.}

Microbacterium sediminis (se.di'mi.nis. L. gen. n. sediminis of sediment, the environment from where the type strain was isolated).

Cells are aerobic, rod-shaped, Gram-positive, oxidasepositive, catalase-positive and motile, and with cell size in the range $0.4-0.7 \times 0.8-1.7 \mu \mathrm{m}$. Colonies are circular, convex with entire margins, moist and white in colour. The temperature range for growth is $4-50{ }^{\circ} \mathrm{C}$, with optimal growth at $28{ }^{\circ} \mathrm{C}$. The $\mathrm{pH}$ range for growth is 5.0-10.0, with optimal growth at $\mathrm{pH} 7.0$. No growth occurs at $\mathrm{NaCl}$ concentrations above $8 \%$ and optimal growth occurs without the addition of $\mathrm{NaCl}$. Demonstrates positive results for catalase, oxidase, D-glucose fermentation, $\beta$ glucosidase (aesculin hydrolysis), $\beta$-galactosidase, potassium gluconate, trisodium citrate, and assimilation of D-fructose, $\alpha$-D-glucose, D-mannitol, D-mannose and 
Table 2. Differential characteristics between strain YLB $-01^{\top}$ and related Microbacterium species

Strains: 1, YLB-01 ${ }^{\mathrm{T}}$; 2, M. hatanonis DSM 19179 ${ }^{\mathrm{T}}$; 3, M. testaceum DSM 20166 ${ }^{\mathrm{T}}$; 4, M. kitamiense Kitami C2 ${ }^{\mathrm{T}}$ (data from Matsuyama et al., 1999); 5, M. phyllosphaerae DSM $13468^{\mathrm{T}}$; 6, M. hydrocarbonoxydans DSM $16089^{\mathrm{T}}$; 7, M. aurantiacum IFO $15234^{\mathrm{T}}$ (Collins et al., 1983; Takeuchi \& Hatano, 1998a, b; Matsuyama et al., 1999); 8, M. schleiferi IFO $15075^{\mathrm{T}}$ (Yokota et al., 1993; Takeuchi \& Hatano, 1998a, b; Bakir et al., 2008); 9, M. barkeri DSM 20145 ${ }^{\mathrm{T}}$ (Komagata \& Suzuki, 1984; Takeuchi \& Hatano, 1998a, b; Brennan et al., 2001); 10, M. paraoxydans CF36 ${ }^{\mathrm{T}}$ (Laffineur et al., 2003); 11, M. profundi Shh $49^{\mathrm{T}}$ (Wu et al., 2008). Data are from this study except where noted. +, Positive; -, negative; w, weakly positive; ND, no data available.

\begin{tabular}{|c|c|c|c|c|c|c|c|c|c|c|c|}
\hline Characteristic & 1 & 2 & 3 & 4 & 5 & 6 & 7 & 8 & 9 & 10 & 11 \\
\hline Colony colour ${ }^{*}$ & WH & LY & $\mathrm{o}$ & $\mathrm{O}$ & Y & $\mathrm{Y}$ & $\mathrm{Y}$ & Y & Y & $\mathrm{Y}$ & $\mathrm{Y}$ \\
\hline \multicolumn{12}{|l|}{ Grown in/at: } \\
\hline $37{ }^{\circ} \mathrm{C}$ & + & - & - & + & + & + & + & + & + & + & - \\
\hline $5 \% \mathrm{NaCl}$ & + & - & + & + & - & - & + & - & & + & + \\
\hline $8 \% \mathrm{NaCl}$ & + & - & - & - & - & - & - & - & & + & - \\
\hline $\begin{array}{l}\text { DNA G }+ \text { C content } \\
(\mathrm{mol} \%)\end{array}$ & 71 & 69 & 67.7 & 69.2 & 64 & ND & 70.3 & 66.5 & 68.7 & 69.9 & 66.8 \\
\hline $\begin{array}{l}\text { Major menaquinones } \\
(\mathrm{MK})\end{array}$ & $\begin{array}{c}8,9,10 \\
11\end{array}$ & 11,12 & 10,11 & 11,12 & $10,11,12$ & 11,12 & 11,12 & $10,11,12$ & 11,12 & 11,12 & 12,13 \\
\hline Cell-wall diamino acid $\dagger$ & Orn & Orn & Orn & Orn & Orn & Orn & Lys & Orn & Orn & Orn & Orn \\
\hline Cell-wall sugars $\ddagger$ & $\begin{array}{l}\text { Rib, Glc, } \\
\text { Gal }\end{array}$ & Rha, Gal & $\begin{array}{l}\text { Rha, Man, } \\
\text { Gal }\end{array}$ & $\mathrm{ND}$ & Gal, Rha & $\mathrm{ND}$ & $\begin{array}{c}\text { Rha, Fuc, } \\
\text { Gal, }\end{array}$ & $\begin{array}{c}\text { 6dTal, Man, } \\
\text { Gal }\end{array}$ & $\begin{array}{l}\text { Rha, Gal, } \\
\text { Glc }\end{array}$ & Glc, Gal & ND \\
\hline \multicolumn{12}{|l|}{ API $50 \mathrm{CH}$ results } \\
\hline D-Fructose & - & - & + & ND & - & - & ND & ND & $\mathrm{ND}$ & ND & + \\
\hline$\alpha$-D-Glucose & + & - & - & + & - & - & + & $\mathrm{w}$ & $\mathrm{ND}$ & + & + \\
\hline D-Mannitol & + & + & - & + & + & + & - & - & - & $\mathrm{ND}$ & + \\
\hline Maltose & + & + & + & ND & $\mathrm{w}$ & + & + & + & $\mathrm{ND}$ & $\mathrm{ND}$ & + \\
\hline D-Mannose & - & - & + & ND & - & $\mathrm{w}$ & + & + & + & $\mathrm{ND}$ & + \\
\hline L-Rhamnose & + & + & - & - & $\mathrm{W}$ & + & + & $\mathrm{ND}$ & + & + & + \\
\hline D-Gluconic acid & - & - & + & ND & - & - & ND & ND & ND & ND & ND \\
\hline L-Alaninamide & $\mathrm{w}$ & - & + & ND & - & - & ND & $\mathrm{ND}$ & $\mathrm{ND}$ & ND & + \\
\hline D-Alanine & $\mathrm{w}$ & - & + & ND & - & - & ND & ND & + & ND & - \\
\hline D-Galactose & $\mathrm{w}$ & - & + & ND & $\mathrm{W}$ & $\mathrm{W}$ & + & ND & + & + & + \\
\hline Gentiobiose & $\mathrm{w}$ & + & + & $\mathrm{ND}$ & - & + & $\mathrm{ND}$ & $\mathrm{ND}$ & $\mathrm{ND}$ & $\mathrm{ND}$ & $\mathrm{ND}$ \\
\hline Sucrose & - & - & + & ND & - & - & + & + & & - & - \\
\hline D-Sorbitol & - & - & + & ND & - & + & $\mathrm{ND}$ & $\mathrm{ND}$ & $\mathrm{ND}$ & ND & $\mathrm{ND}$ \\
\hline \multicolumn{12}{|l|}{ API ZYM results } \\
\hline $\begin{array}{l}\text { Alkaline } \\
\text { phosphatase }\end{array}$ & + & $\mathrm{W}$ & + & ND & $\mathrm{W}$ & - & ND & - & $\mathrm{ND}$ & $\mathrm{ND}$ & $\mathrm{ND}$ \\
\hline Esterase (C8) & + & + & + & $\mathrm{ND}$ & $\mathrm{w}$ & $\mathrm{w}$ & $\mathrm{ND}$ & - & + & - & ND \\
\hline Lipase (C14) & $\mathrm{w}$ & + & + & ND & + & - & ND & $\mathrm{ND}$ & $\mathrm{ND}$ & ND & ND \\
\hline Trypsin & + & + & + & ND & + & $\mathrm{w}$ & ND & $\mathrm{w}$ & $\mathrm{ND}$ & ND & $\mathrm{ND}$ \\
\hline$\alpha$-Chymotrypsin & + & - & + & ND & + & - & ND & - & $\mathrm{ND}$ & $\mathrm{ND}$ & $\mathrm{ND}$ \\
\hline$\alpha$-Galactosidase & + & - & + & ND & + & $\mathrm{w}$ & ND & - & $\mathrm{ND}$ & ND & $\mathrm{ND}$ \\
\hline$\beta$-Galactosidase & $\mathrm{w}$ & + & + & $\mathrm{ND}$ & + & + & $\mathrm{ND}$ & + & $\mathrm{ND}$ & $\mathrm{ND}$ & $\mathrm{ND}$ \\
\hline$\beta$-Glucuronidase & + & $\mathrm{w}$ & + & ND & W & $\mathrm{W}$ & ND & - & ND & ND & ND \\
\hline$\alpha$-Glucosidase & - & + & + & ND & + & + & ND & + & - & + & ND \\
\hline$\beta$-Glucosidase & - & + & + & ND & + & + & ND & + & + & - & ND \\
\hline $\begin{array}{l}N \text {-Acetyl- } \beta \text { - } \\
\text { glucosaminidase }\end{array}$ & + & - & + & - & - & + & + & - & + & + & - \\
\hline$\alpha$-Mannosidase & + & - & + & ND & + & + & ND & - & $\mathrm{ND}$ & ND & $\mathrm{ND}$ \\
\hline \multicolumn{12}{|l|}{ API 20NE results } \\
\hline Gelatin hydrolysis & - & - & - & ND & + & - & ND & $\mathrm{ND}$ & ND & ND & $\mathrm{ND}$ \\
\hline L-Arabinose & - & + & + & $\mathrm{ND}$ & + & + & ND & $\mathrm{ND}$ & ND & $\mathrm{ND}$ & $\mathrm{ND}$ \\
\hline Malic acid & $\mathrm{w}$ & - & + & ND & + & + & ND & ND & ND & $\mathrm{ND}$ & $\mathrm{ND}$ \\
\hline Phenylacetic acid & - & - & - & $\mathrm{ND}$ & - & $\mathrm{w}$ & ND & $\mathrm{ND}$ & ND & ND & ND \\
\hline
\end{tabular}

${ }^{*}$ WH, white; LY, light yellow; O, orange; y, yellow.

$\dagger$ Lys, lysine; Orn, ornithine.

¥Rib, ribose; 6dTal, 6-deoxytalose; Fuc, fucose; Gal, galactose; Glc, glucose; Rha, rhamnose; Man, mannose. 
D-sorbitol. Weakly positive results in tests for D-gluconic acid, L-alaninamide, D-alanine, L-alanyl glycine and Dgalactose. Gives positive results for the production of alkaline phosphatase, esterase lipase (C8), lipase (C14), leucine aminopeptidase, valine aminopeptidase, cystine aminopeptidase, trypsin, $\alpha$-chymotrypsin, acid phosphatase, $\beta$-galactosidase, $\beta$-glucosidase and $N$-acetyl- $\beta$-glucosaminidase. Shows negative results for nitrate reduction, indole production, arginine dihydrolase, urease, utilization of L-arabinose, capric acid, adipic acid and phenylacetic acid, and for production of naphthol-AS-BI-phosphoamidase, $\beta$-glucuronidase, $\alpha$-glucosidase, $\alpha$-mannosidase and $\alpha$-fucosidase. Cell-wall hydrolysate contains the amino acids ornithine, alanine, glycine homoserine and glutamic acid, and the cell-wall sugars are ribose, glucose and galactose. The menaquinones are MK-10, MK-11, MK-8, MK-9 and MK-12 and some unidentified minor components. The major cellular fatty acids are anteiso- $\mathrm{C}_{15: 0}$, anteiso- $\mathrm{C}_{17: 0}$ and $\mathrm{C}_{16: 0}$. The polar lipids are diphosphatidylglycerol, phosphatidylglycerol, an unidentified phospholipid and two unidentified glycolipids.

The type strain, YLB- $01^{\mathrm{T}} \quad\left(=\mathrm{DSM} \quad 23767^{\mathrm{T}}=\mathrm{CCTCC}\right.$ $\mathrm{AB} 2010363^{\mathrm{T}}=$ MCCC $1 \mathrm{~A} 06153^{\mathrm{T}}$ ), was isolated from sediment of the Indian Ocean. The DNA G $+\mathrm{C}$ content of the type strain is $71 \mathrm{~mol} \%$.

\section{Acknowledgements}

This study was supported by Science and Technology project of Xiamen (3502Z20111051) and the R\&D Special Fund for Public Welfare Industry (Oceanography) (201005022-1, 201005032-1).

\section{References}

Altschul, S. F., Madden, T. L., Schäffer, A. A., Zhang, J., Zhang, Z., Miller, W. \& Lipman, D. J. (1997). Gapped BLAST and PSI-BLAST: a new generation of protein database search programs. Nucleic Acids Res 25, 3389-3402.

Bakir, M. A., Kudo, T. \& Benno, Y. (2008). Microbacterium hatanonis sp. nov., isolated as a contaminant of hairspray. Int J Syst Evol Microbiol 58, 654-658.

Behrendt, U., Ulrich, A. \& Schumann, P. (2001). Description of Microbacterium foliorum sp. nov. and Microbacterium phyllosphaerae sp. nov., isolated from the phyllosphere of grasses and the surface litter after mulching the sward, and reclassification of Aureobacterium resistens (Funke et al. 1998) as Microbacterium resistens comb. nov. Int J Syst Evol Microbiol 51, 1267-1276.

Brennan, N. M., Brown, R., Goodfellow, M., Ward, A. C., Beresford, T. P., Vancanneyt, M., Cogan, T. M. \& Fox, P. F. (2001). Microbacterium gubbeenense sp. nov., from the surface of a smearripened cheese. Int J Syst Evol Microbiol 51, 1969-1976.

Chun, J. \& Goodfellow, M. (1995). A phylogenetic analysis of the genus Nocardia with $16 \mathrm{~S}$ rRNA gene sequences. Int J Syst Bacteriol 45 240-245.

Chun, J., Lee, J. H., Jung, Y., Kim, M., Kim, S., Kim, B. K. \& Lim, Y. W. (2007). EzTaxon: a web-based tool for the identification of prokaryotes based on $16 \mathrm{~S}$ ribosomal RNA gene sequences. Int J Syst Evol Microbiol 57, 2259-2261.
Collins, M. D. \& Bradbury, J. F. (1992). The genera Agromyces, Aureobacterium, Clavibacter, Curtobacterium, and Microbacterium. In The Prokaryotes, pp. 1355-1368. Edited by A. Balows, H. G. Trüper, M. Dworkin, H. Harder \& K.-H. Schleifer. Berlin: Springer.

Collins, M. D., Jones, D. \& Kroppenstedt, R. M. (1983). Reclassification of Brevibacterium imperiale (Steinhaus) and 'Corynebacterium laevaniformans' (Dias and Bhat) in a redefined genus Microbacterium (OrlaJensen), as Microbacterium imperiale comb. nov. and Microbacterium laevaniformans comb. rev., comb. nov. Syst Appl Microbiol 4, 65-78.

Felsenstein, J. (1985). Confidence limits on phylogenies: an approach using the bootstrap. Evolution 39, 783-791.

Groth, I., Schumann, P., Weiss, N., Martin, K. \& Rainey, F. A. (1996). Agrococcus jenensis gen. nov., sp. nov., a new genus of actinomycetes with diaminobutyric acid in the cell wall. Int J Syst Bacteriol 46, 234239.

Komagata, K. \& Suzuki, K.-I. (1984). Genus Aureobacterium Collins, Jones, Keddie, Kroppenstedt and Schleifer 1983, 672 ${ }^{\mathrm{VP}}$. In Bergey's Manual of Systematic Bacteriology, vol. 2, pp. 1323-1325. Edited by J. T. Staley, M. P. Bryant, N. Pfennig \& J. G. Holt. Baltimore: Williams \& Wilkins.

Kumar, S., Tamura, K. \& Nei, M. (2004). MEGA3: integrated software for molecular evolutionary genetics analysis and sequence alignment. Brief Bioinform 5, 150-163.

Laffineur, K., Avesani, V., Cornu, G., Charlier, J., Janssens, M., Wauters, G. \& Delmée, M. (2003). Bacteremia due to a novel Microbacterium species in a patient with leukemia and description of Microbacterium paraoxydans sp. nov. J Clin Microbiol 41, 2242-2246.

Lai, Q., Yuan, J., Wang, B., Sun, F., Qiao, N., Zheng, T. \& Shao, Z. (2009). Bowmanella pacifica sp. nov., isolated from a pyrenedegrading consortium. Int J Syst Evol Microbiol 59, 1579-1582.

MacKenzie, S. L. (1987). Gas chromatographic analysis of amino acids as the N-heptafluorobutyryl isobutyl esters. J Assoc Off Anal Chem 70, 151-160.

Madhaiyan, M., Poonguzhali, S., Lee, J. S., Lee, K. C., Saravanan, V. S. \& Santhanakrishnan, P. (2010). Microbacterium azadirachtae sp. nov., a plant-growth-promoting actinobacterium isolated from the rhizoplane of neem seedlings. Int J Syst Evol Microbiol 60, 1687-1692.

Matsuyama, H., Kawasaki, K., Yumoto, I. \& Shida, O. (1999). Microbacterium kitamiense sp. nov., a new polysaccharide-producing bacterium isolated from the wastewater of a sugar-beet factory. Int $J$ Syst Bacteriol 49, 1353-1357.

Mesbah, M., Premachandran, U. \& Whitman, W. B. (1989). Precise measurement of the $\mathrm{G}+\mathrm{C}$ content of deoxyribonucleic acid by highperformance liquid chromatography. Int J Syst Bacteriol 39, 159-167.

Minnikin, D. E., O’Donnell, A. G., Goodfellow, M., Alderson, G., Athalye, M., Schaal, A. \& Parlett, J. H. (1984). An integrated procedure for the extraction of bacterial isoprenoid quinones and polar lipids. J Microbiol Methods 2, 233-241.

Orla-Jensen, S. (1919). The Lactic Acid Bacteria. Copenhagen: Host and Sons.

Saitou, N. \& Nei, M. (1987). The neighbor-joining method: a new method for reconstructing phylogenetic trees. Mol Biol Evol 4, 406425.

Sasser, M. (1990). Identification of bacteria by gas chromatography of cellular fatty acids, MIDI Technical Note 101. Newark, DE: MIDI Inc.

Schippers, A., Bosecker, K., Spröer, C. \& Schumann, P. (2005). Microbacterium oleivorans sp. nov. and Microbacterium hydrocarbonoxydans sp. nov., novel crude-oil-degrading Gram-positive bacteria. Int J Syst Evol Microbiol 55, 655-660.

Schleifer, K. H. (1985). Analysis of the chemical composition and primary structure of murein. Methods Microbiol 18, 123-156. 
Schumann, P. \& Evtushenko, L. I. (2006). International Committee on Systematics of Prokaryotes Subcommittee on the taxonomy of the suborder Micrococcineae. Minutes of the meeting, 24 July 2005, San Francisco, CA, USA. Int J Syst Evol Microbiol 56, 27212722 .

Schumann, P., Rainey, F. A., Burghardt, J., Stackebrandt, E. \& Weiss, N. (1999). Reclassification of Brevibacterium oxydans (Chatelain and Second 1966) as Microbacterium oxydans comb. nov. Int J Syst Bacteriol 49, 175177.

Stach, J. E. \& Bull, A. T. (2005). Estimating and comparing the diversity of marine actinobacteria. Antonie van Leeuwenhoek 87, 3 9.

Staneck, J. L. \& Roberts, G. D. (1974). Simplified approach to identification of aerobic actinomycetes by thin-layer chromatography. Appl Microbiol 28, 226-231.

Takeuchi, M. \& Hatano, K. (1998a). Union of the genera Microbacterium Orla-Jensen and Aureobacterium Collins et al. in a redefined genus Microbacterium. Int J Syst Bacteriol 48, 739747.

Takeuchi, M. \& Hatano, K. (1998b). Proposal of six new species in the genus Microbacterium and transfer of Flavobacterium marinotypicum ZoBell and Upham to the genus Microbacterium as Microbacterium maritypicum comb. nov. Int J Syst Bacteriol 48, 973982.

Thompson, J. D., Gibson, T. J., Plewniak, F., Jeanmougin, F. \& Higgins, D. G. (1997). The CLUSTAL_X windows interface: flexible strategies for multiple sequence alignment aided by quality analysis tools. Nucleic Acids Res 25, 4876-4882.
Tindall, B. J. (1990a). A comparative study of the lipid composition of Halobacterium saccharovorum from various sources. Syst Appl Microbiol 13, 128-130.

Tindall, B. J. (1990b). Lipid composition of Halobacterium lacusprofundi. FEMS Microbiol Lett 66, 199-202.

Whiton, R. S., Lau, P., Morgan, S. L., Gilbart, J. \& Fox, A. (1985). Modifications in the alditol acetate method for analysis of muramic acid and other neutral and amino sugars by capillary gas chromatography-mass spectrometry with selected ion monitoring. J Chromatogr A 347, 109-120.

Wu, Y. H., Wu, M., Wang, C. S., Wang, X. G., Yang, J. Y., Oren, A. \& Xu, X.W. (2008). Microbacterium profundi sp. nov., isolated from deep-sea sediment of polymetallic nodule environments. Int J Syst Evol Microbiol 58, 2930-2934.

Xu, M., Wang, F., Meng, J. \& Xiao, X. (2007). Construction and preliminary analysis of a metagenomic library from a deep-sea sediment of east Pacific Nodule Province. FEMS Microbiol Ecol 62, 233-241.

Yokota, A., Takeuchi, M., Sakane, T. \& Weiss, N. (1993). Proposal of six new species in the genus Aureobacterium and transfer of Flavobacterium esteraromaticum Omelianski to the genus Aureobacterium as Aureobacterium esteraromaticum comb. nov. Int J Syst Bacteriol 43, 555-564.

Young, C. C., Busse, H. J., Langer, S., Chu, J. N., Schumann, P., Arun, A. B., Shen, F. T., Rekha, P. D. \& Kämpfer, P. (2010). Microbacterium agarici sp. nov., Microbacterium humi sp. nov. and Microbacterium pseudoresistens sp. nov., isolated from the base of the mushroom Agaricus blazei. Int J Syst Evol Microbiol 60, 854-860. 